\title{
Skin Grafted Tubularized Incised Urethral Plate for Penile Hypospadias Repair
}

\author{
Mazen O. Kurdi, MSC, FRSC(I) \\ Department of Pediatric Surgery, Faculty of Medicine \\ King Abdulaziz University, Jeddah, Saudi Arabia
}

\section{Correspondence \\ Dr. Mazen O. Kurdi \\ P. O. Box 80215, Jeddah 21589, Saudi Arabia \\ e-M: mokurdi@gmail.com \\ Submission: 9 Mar. 2015 \\ Accepted: $\quad 2$ June 2015}

\section{Citation}

Kurdi MO. Skin grafted tubularized incised urethral plate for penile hypospadias repair. JKAU Med Sci 2015; 22(3): 41-45.

DOI: 10.4197/Med. 22.3.6

\begin{abstract}
Hypospadias is a fairly common congenital defect wherein the urinary tract opening is mispositioned on the ventral aspect of the penis in newborn males. Many techniques have been attempted for the repositioning. Skin grafting of the incised urethral plate was first used in 1998 with encouraging results. This prospective study reports the results of performing this surgical technique at King Abdulaziz University hospital over the period from January 2010 to December 2014. Thirty patients were enrolled with penile hypospadias, 15 patients had shallow urethral plate, nine patients had small glans and 6 patients had scarred urethral plate as a result of a previous hypospadias operation. We used continuous suturing (or multiple interrupted stitches) of the proximal end of the skin graft with single stitch fixation of the graft to the depth of the incised urethral plate which helps prevent the separation of the graft by the urinary stream and improve the graft taking. All patients had good caliber of the urethral meatus and the grafted neourethra. Two patients developed urethra-cutaneous fistula without meatal or neourethral stenosis. Grafting of the urethral plate should be considered as an adjunctive method for hypospadias repair especially in patients with small glans, shallow or scarring urethral plate. This grafting resulted in good caliber urethral meatus and neourethra.
\end{abstract}

\section{Keywords}

Hypospadias; Uretheral plate; Snoodgraft; Reoperation; Skin graft

\section{Introduction}

$T$ ubularized incised plate (TIP) urethroplasty was first reported in 1994 as a reparative method for the treatment of distal penile hypospadias and since then it has become one of the most popular techniques for repairing not only the distal, but also some of the proximal hypospadias ${ }^{[1]}$. A major concern with this technique pertains to the required incision which, similar to urethrotomy, risks scarring, vice the development of new epithelial cells, and thus subsequent neouretheral or meatal stricture ${ }^{[2-4]}$. In 1998 Spagnoli et al., first presented a modification of TIP wherein the urethral plate was incised and skin grafted before tubularization ${ }^{[5]}$. Subsequently this modified technique was used by others as the inlay or Snodgraft procedure with good results for primary and redo hypospadias and improved results of hypospadias repair with regards to prevention of meatal and neourethral stricture ${ }^{[6-13]}$. 
In this study we present our experience in repairing the penile hypospadias with skin grafting of the incised urethral plate; stressing the effectiveness of sealing the proximal end of the graft by continuous suturing (or multiple interrupted stitches) of the proximal end of the skin graft to the urethra to prevent the separation of the graft by the urine stream and promote deep epithelialization of the groove by applying a stitch to fix the graft deeply into the groove of the incised urethral plate which maintains good caliber neourethra.

\section{Patients and Method}

This prospective study reports the results of performing the skin graft of the incised urethral plate in tabularized urethroplasty of penile hypospadias at King Abdulaziz University Hospital over the period from January, 2010 to December 2014. Thirty patients were enrolled with penile hypospadias. The indications in our patients were: shallow, narrow urethral plate in 15 patients; small glans in nine patients; and scarred urethral plate as a result of a previous hypospadias operation in six patients. All patients were admitted to the pediatric surgical unit one night prior to the procedure; a first dose of third-generation cephalosporin was given at the time of induction of the operation and continued for five days after the operation. The size of the urethral catheter was determined based on the breadth of the urethral plate, either an $8 \mathrm{~F}$ or $10 \mathrm{~F}$, and a $6 / 0$ polyglactin was applied at the tip of the decided newly formed meatus. The urethral plate was incised from the site of the hypospadic meatus to the site of the newly formed meatus; the decision whether to also incise the glans was dependent on the size of the glans itself. The graft was usually harvested from the inner dorsal skin of the prepuce, otherwise from the medial aspect of the arm in a non-hairy area. Subsequently the graft was sutured overlying the incision line with $6 / 0$ polyglactin and the proximal part of the graft was sutured by continuous stitch (or multiple interrupted stitches) to prevent separation of the graft by the passage of the urine stream behind the graft. Additionally we applied one stitch to the center of the graft to affix it deeply to prevent stenosis by scarring in the depth of the incision to promote better epithelialization of the groove (Figs. 1, 2, and 3). Urethroplasty was done using $6 / 0$ polyglactin, a second layer was used either by transposed dorsal dartos (buttonhole or rotational), or local subcutaneous or tunica vaginalis flaps. The catheter was removed on the $7^{\text {th }}$ post-operative day; follow up at the pediatric surgical clinic at 1, 2 weeks and 1 month and finally at 3 months. To avoid

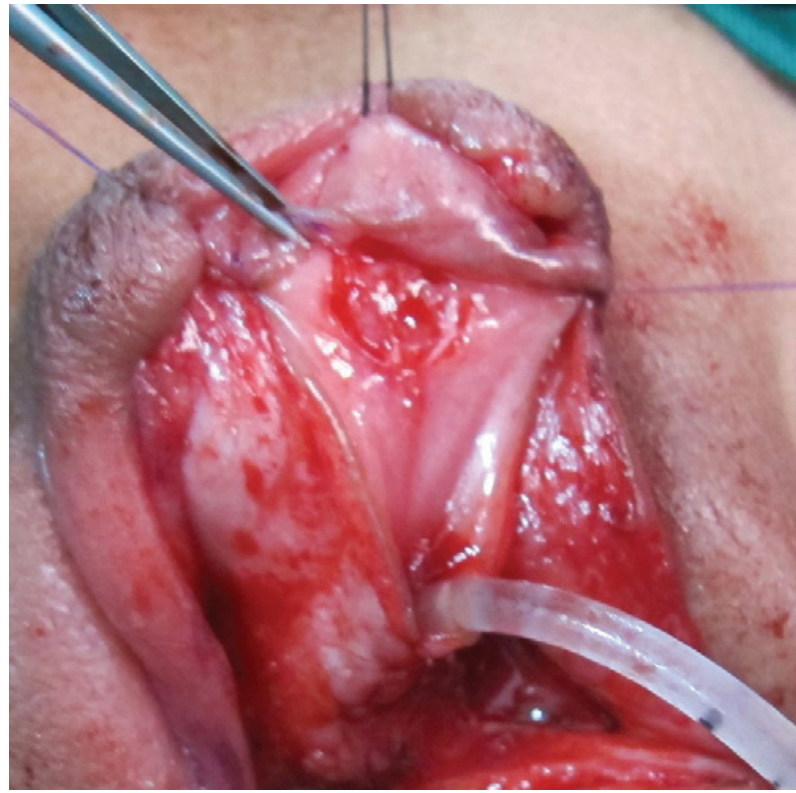

Figure 1. Penile hypospadias with small glans penis incision of the urethral plate prepared for skin grafting.

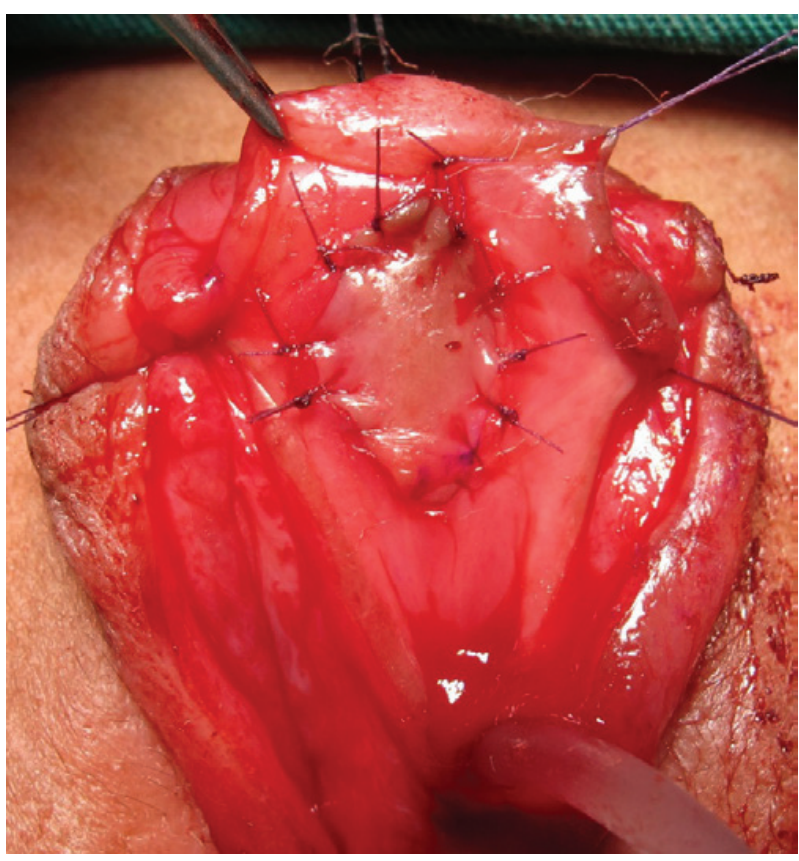

Figure 2. Skin grafted incised urethral plate. Graft fixed with $6 / 0$ interrupted polyglactin stitches but proximal end of the graft fixed by continuous stitch to prevent the separation of the graft by the urine stream and deep epithelialization of the groove by applying a stitch (on undersurface of the graft) to fix the graft deeply into the groove of the incised urethral plate, which maintains good caliber neourethra. 


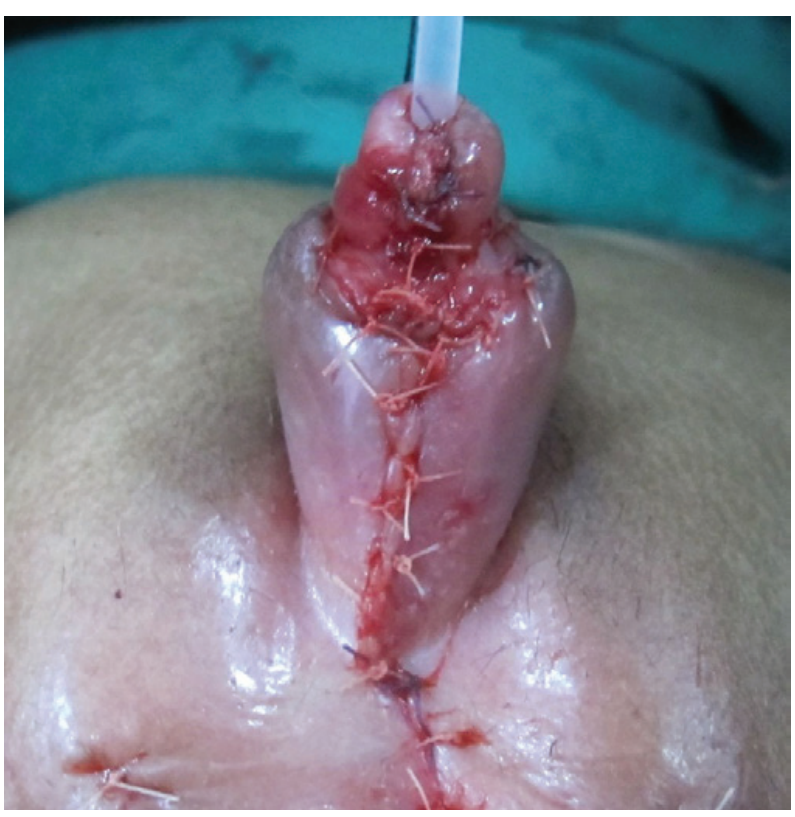

Figure 3. The glans penis could be closed comfortably over the tubularized incised grafted urethral plate.

dislodging the graft, calibration was not done in the first 2 post-operative weeks but at the 4 week OPD visit to evaluate the caliber of the meatus and the urethra.

\section{Results}

Harvesting and grafting procedure required a mean time of $60-90$ minutes. At $4^{\text {th }}$ week and 3 months follow-up visit all patients displayed good caliber of the meatus and neourethra, freely accommodating a size $8 \mathrm{Fr}$ urethral dilator. No immediate post-operative complications but two patients developed tiny coronal urethro-cutaneous fistula in spite of good caliber of the meatus and the neourethra, both of these patients had undergone redo urethroplasty.

\section{Discussion}

In 1941 Humby and Higgins ${ }^{[14]}$ reported the first hypospadias repair procedure utilizing the application of skin grafts. Devine and Horton ${ }^{[15]}$ reported the utilization of a preputial skin graft for a hypospadias repair procedure in 1961 . The practice of harvesting grafts for surgical hypospadias repair has subsequently seen wide adoption, with surgeons obtaining the necessary grafts from various different regions of the body, including the prepuce, bladder mucosa and, more recently, even the buccal mucosa ${ }^{[16-19]}$. Tabularized incised plate urethroplasty was first reported in 1994 as a treatment for distal penile hypospadias and has since become the surgical method of choice for repairing the distal, and some of the proximal, hypospadias ${ }^{[20]}$. But a prior surgery, particularly if it involved an incision of the urethral plate, may reduce the vascularity of the urethral plate negatively impacting the success of a later incision and tubularization. With this in mind, the precautionary advice of some practitioners is to avoid this method if the plate appears to have undergone a prior surgical alteration ${ }^{[21-23]}$.

Regardless of the indication of the urethral plate grafting, whether for primary or reoperation of hypospadias patients, the decision is made mainly because of the underlying anatomical abnormality which might be small glans, shallow urethral plate or the existence of scar tissue in the urethral plate. Although the onlay island flap might represent another alternative to gain some more width of the urethral plate as Powell et al. ${ }^{[24]}$ reported in 1999 when he reviewed the application of an epithelial free graft against the transverse preputial island flap. They could not see any substantive fluctuation in the risk of complication and consequently judged that a free graft is an acceptable option in place of flap urethroplasty. Another considerable study was done by Kolon and Gonzales ${ }^{[6]}$ in 2000 which concluded that the dorsal inlay graft after midline incision of the urethral plate meets the primary aims of hypospadias surgery and is especially helpful for complex or proximal hypospadias when a transverse preputial island flap is under consideration. Additional surgical modifications, such as beginning the urethral suture with a meatal stitch as suggested by Jayanthi ${ }^{[25]}$ and limiting the glans wings incision to the neomeatal level, help the surgeon achieve a wide, scarfree neourethral meatus, decreasing the complication rate. In our prospective study we did not experience any urethral or meatal stenosis. We believe that the graft taking was successful in all cases and the proximal continuous suturing of the graft to the urethra and the fixation of the graft to the depth of the incised plate helped to insure a high chance of graft taking.

\section{Conclusion}

The author recommends grafting of the incised urethral plate be considered as an alternative method of surgical treatment for hypospadias patients, especially in cases with shallow urethral plate or small glans as well as when there is scarring of the urethral plate. Sealing of the proximal end of the graft to the urethra and affixing the graft to the depth of the incision helped ensure better taking of the graft with 
wider caliber neourethra. Application of the Snodgraft procedure yields a good caliber functional neourethra and a good caliber vertical slit meatus.

\section{Conflict of Interest}

The author has no conflict of interest.

\section{Disclosure}

The author did not receive any type of commercial support either in forms of compensation or financial for this study. The author has no financial interest in any of the products or devices, or drugs mentioned in this article.

\section{Ethical Approval}

Obtained.

\section{References}

[1] Snodgrass W. Tubularized, incised plate urethroplasty for distal hypospadias. J Urol 1994; 151(12): 464-465.

[2] Rich MA. Keating MA, Snyder HM, Duckett JW. Hinging the urethral plate in hypospadias meatoplasty. J Urol 1989; 142(6): 1551-1553.

[3] Zaontz MR. The GAP (glans approximation procedure) for glanular/coronal hypospadias. J Urol 1989; 141(2): 359- 361.

[4] Snodgrass W. Does tubularized incised plate hypospadias repair create neourethral strictures? J Urol 1999; 162(3 Pt 2): 1159-1161.

[5] Spagnoli A, Zaccara A, Ferro F. Snodgrass urethroplasty: grafting the incised plate. Presented at annual meeting of American Academy of Pediatrics, Section on Urology, San Francisco, California, 1998, p 141.

[6] Kolon TF, Gonzales ET Jr. The dorsal inlay graft for hypospadias repair. J Urol 2000; 163(6): 1941-1943.

[7] Gundeti M, Queteishat A, Desai D, Cuckow P. Use of an inner preputial free graft to extend the indications of Snodgrass hypospadias repair (Snodgraft). J Pediatr Urol 2005; 1(6): 395-396.

[8] Asanuma H, Satoh $H$, Shishido S. Dorsal inlay graft urethroplasty for primary hypospadiac repair. Int J Urol 2007; 14(1): 43-47.

[9] Singh RB, Pavithran NM. Lessons learnt from Snodgrass tip urethroplasty: a study of 75 cases. Pediatr Surg Int 2004; 20(3): 204-206.

[10] Ferro F, Vallasciani S, Borsellino A, Atzori P, Martin L. Snodgrass urethroplasty: grafting the incised plate-10 years later. J Urol 2009; 182 (4 Suppl): 1730

[11] Hayes MC, Malone PS. The use of a dorsal buccal mucosal graft with urethral plate incision (Snodgrass) for hypospadias salvage. BJU Int 1999; 83(4): 508-509.
[12] Schwentner C, Gozzi C, Lunacek A, Rehder P, Bartsch $G$, Oswald J, Radmayr C. Interim outcome of the single stage dorsal inlay skin graft for complex hypospadias reoperations. J Urol 2006; 175(5): 1872-1876.

[13] Silay MS, Sirin H, Tepeler A, Karatag T, Armagan A, Horasanli K, Miroglu C. "Snodgraft" technique for the treatment of primary distal hypospadias: pushing the envelope. J Urol 2012; 188(3): 938-942.

[14] HUMBY G, HIGGINS TT. A one-stage operation for hypospadias. Br J Surg 1941; 29: 84-92.

[15] DEVINE C JR, HORTON C. A one-stage hypospadias repair. J Urol 1961; 85: 166.

[16] Hendren WH, Keating MA. Use of dermal graft and free urethral graft in penile reconstruction. J Urol 1988; 140(5 Pt 2): 1265-1269.

[17] King LR. Bladder mucosal grafts for severe hypospadias: a successful technique. J Urol 1994; 152 (6 Pt 2): 2338-2340.

[18] Dessanti A, Rigamonti W, Merulla V, Falchetti D, Caccia G. Autologous buccal mucosa graft for hypospadias repair: an initial report. J Urol 1992; 147(4): 1081-1084.

[19] Baskin LS, Duckett JW. Buccal mucosa grafts in hypospadias surgery. Br J Urol 1995; 76 Suppl 3: 23-30.

[20] Kaplan GW. Repair of proximal hypospadias using a preputial free graft for neourethral construction and a preputial pedicle flap for ventral skin coverage. J Urol 1988; 140(5 Pt 2): 1270-1272.

[21] Shanberg AM, Sanderson K. Duel B. Re-operative hypospadias repair using the Snodgrass incised plate urethroplasty. BJU Int 2001; 87(6): 544-547.

[22] Borer JG, Bauer SB, Peters CA, Diamond DA, Atala A, Cilento BG Jr, Retik AB. Tubularized incised plate urethroplasty: expanded use in primary and repeat surgery for hypospadias. J Urol 2001; 165(2): 581-585.

[23] Yang SS, Chen SC, Hsieh CH, Chen YT. Reoperative Snodgrass procedure. J Urol 2001; 166(6): 2342-2345.

[24] Powell CR, Mcaleer I, Alagiri M, Kaplan GW. Complications of preputial island flap vs free graft hypospadias repairs. J Urol 2000; 163(4): 108.

[25] Jayanthi VR. The modified Snodgrass hypospadias repair: reducing the risk of fistula and meatal stenosis. J Urol 2003; 170(4 Pt 2): 1603-1605. 


\section{الترقيع الجلدي لجرح قطعي خلفي في مجرى البول قبل تكوين انبوب الاحليل في عمليات الاحليل السقلي بالقضيب}

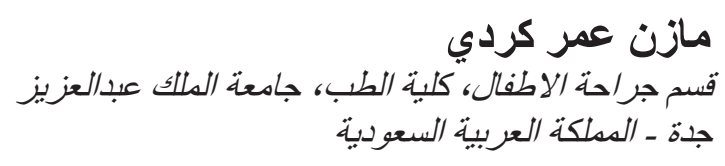

المستخلص. الاحليل البولي السفلي من العيوب الخلقية الثائعة عند الذكور حيث تكون فتحة البول في الجهه السفلية من القضيب. وقد استخدمت العديد من الطرق الجراحية لتصديح موقع الفتحة. وفي 991 ام استخدم لاول مرة الترقيع الجلدي لقطع في مجرى البول قبل نكوين انبوب الاحليل في عمليات الاحليل السفلي. وكانت النتائج مشجعة. هذه الدر اسة المستقبلية

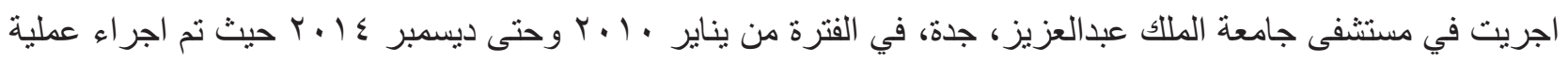

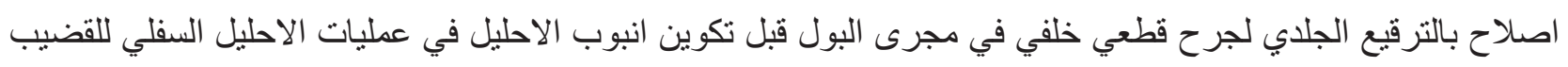

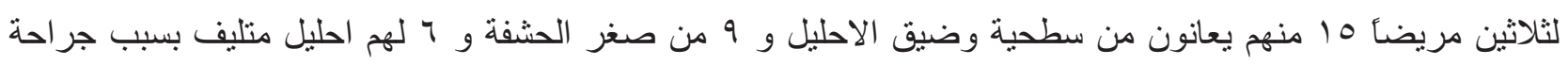

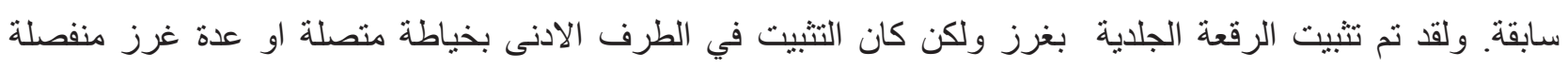

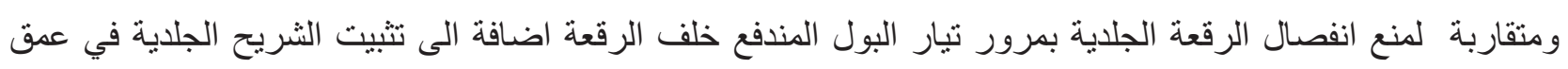

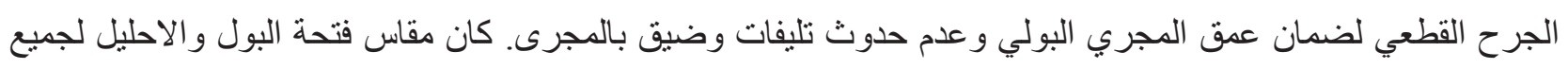

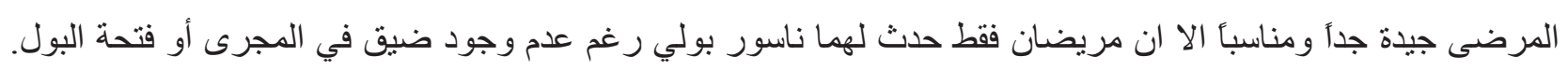

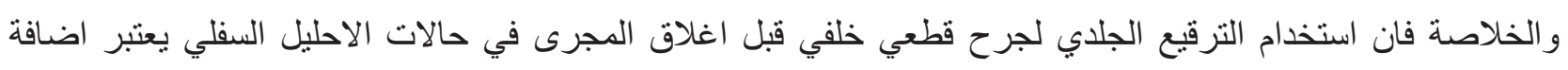

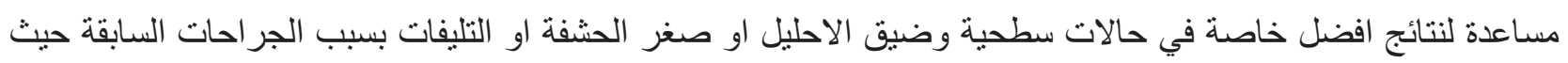

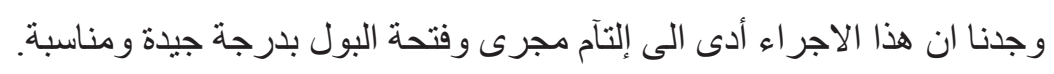

